\title{
Internal governance imperatives for universities
}

\begin{abstract}
In a world of increasing concern about corporate governance, universities should be at the forefront of role modelling sound governance and promoting the development of moral standards in society in accordance with one of their central mandates. This paper argues that compliance with relevant legislation and higher education policy of the country is a necessary but not a sufficient condition for sound and meaningful governance within universities. What is also required is the exposing and addressing of those 'less easy to articulate' and often subtle practices that render meaningless espoused values and that hamper full collegiality that can contribute to the achievement of university objectives. In addition, this omission has resulted in poor role modelling of governance standards to students who pass through universities on their way to becoming future leaders and decision-makers. These are the students who may translate their university experience into the way they influence, in some way, the moral standards of society. The paper concludes by posing three questions, as a start, to guide the interrogation of governance and to begin the process of developing moral responsibility at universities.
\end{abstract}

Key words: universities, governance, ethics, South Africa, moral responsibility

\section{Introduction}

Significant corporate transgressions have led to an international focus on governance with increasing societal scrutiny of public institutions, including those in the education arena that have thus far eluded serious public gaze (Kelley \& Chang, 2007; Pounder, 2001). There appears to be a growing trend for higher education stakeholders to monitor productivity and accountability in their institutions (Martin \& Marion, 2005; McAlpine $\&$ Harris, 2002) and to demand that such institutions demonstrate 'value for money performance' (Pounder, 2002: 458). However, while there is a focus on 'value for money performance' and on the broader accountability of universities, the areas of scrutiny by society, by government, and perhaps by universities themselves have fallen somewhat short of the target. The wrong questions or insufficient questions have been asked to ascertain accountability.

In a world of increasing concern about matters of corporate governance, universities should be at the

Adele Thomas is a professor in the Department of Business Management at the University of Johannesburg. Her research, teaching and consulting areas include business ethics and corporate governance, governance in universities, and valuesbased organisational cultures. forefront of role modelling sound governance and promoting the development of moral standards in society in accordance with one of their central mandates. However, it is proposed that South African universities have slowly abdicated their role of influencing moral behaviour in society. This is largely due to the lack of addressing internal governance challenges in a manner that would command the same priority as any other phenomenon worthy of interrogation in the academy.

This paper argues that compliance with relevant legislation and higher education policy of the country is a necessary but not a sufficient condition for sound and meaningful governance within universities. What is also required is the exposing and addressing of those 'less easy to articulate' and often subtle practices that render meaningless espoused values and that hamper full collegiality that can contribute to the achievement of university objectives. In addition, this omission has resulted in poor role modelling of governance standards to students who pass through our institutions on their way to becoming future leaders and decisionmakers, many of whom will surely influence the moral standards of society in some way. The paper progresses this argument by discussing the university mandate and its execution as well as the practices and culture of the university as a context within which student academic dishonesty occurs. The paper concludes with a challenge to universities to develop institutional moral responsibility as a foundation for sound governance.

\section{The university mandate}

One of the main goals of education, dating back to early western civilisation, is the development of ethical and moral members of society (McWilliams \& Nahavandi, 2006). Plato believed that education 'makes good men, and that good men act nobly' (quoted in McBee, 1980:5). Lickona (1991:6) notes that 'wise societies since the time of Plato ... have educated for character as well as intellect, decency as well as literacy, virtue as well as knowledge'. Hogness (1986:562) stresses that 'morality ... learning from right and wrong ... is the essence of education'.

A core reason for the existence of universities is to develop thought and moral leadership in society through teaching, research and community service. With regard to thought leadership, the Committee of University Chairmen (1998:1) notes that '(i)nstitutions of higher education are characterised by a distinctive ethos. Despite diverse backgrounds and traditions, they are united in the common purpose of the provision of 
teaching and the pursuit of knowledge and research'. When considering the development of moral leadership, Rantz (2002:458) regards the university as being founded on a system of ethics, where the "concept of "right" exists within a deeper purpose toward society, and [is] held together by the loyalty to that purpose'. Universities are 'moral ventures' that are guided by what is ethically right and fundamentally good (LeRoy Long, 1992:35) with one of the goals being to 'produce a virtuous populace, one that is morally mature and spiritually grounded' (Howard, 1986:318).

Until the middle of the 20th century, post graduate education, taking up this challenge, aimed at developing the moral character of students (McWilliams \& Nahavandi, 2006). This endeavour was perhaps best exemplified by the teaching of a mandatory capstone course for students on moral philosophy by the former President of Harvard University himself (Bok, 1990). The university, accordingly, contributes to both intellectual progress in, and the moral transformation of society through, the generation of thought leadership and the influencing of moral debate. Summing up this position, the UN Global Compact (2007:3) states of universities that they 'help shape the attitudes and behavior of business leaders through business education, research, management development programs, training, and other pervasive, but less tangible activities, such as the spread and advocacy of new values and ideas'.

This charge places an enormous responsibility on universities. Universities are there, not only to progress thought leadership through accomplished graduates but to graduate students who also carry forward moral leadership in society, and, who, in this way, influence social transformation. Again, the UN Global Compact (2007:3) notes that business requires talented and ethical leaders who can not only advance organisational goals and fulfill (sic) legal and fiduciary obligations to shareholders, but who are also prepared to deal with the broader impact and potential of business as a positive global force in society'. In this vein, T.S. Eliot (1962:123) noted: 'No university ought to be merely a national institution ... They should not be institutions for the training of an efficient bureaucracy, or for equipping scientists to get the better of foreign scientists; they should stand for the preservation of learning, for the pursuit of truth, and, in so far as men are capable of it, the attainment of wisdom.'

\section{Executing the mandate}

Perhaps one of the most overt symptoms of something 'going wrong' is the extent of dishonesty in society. Corruption in society continues to prevail (Control Risks Group, 2006) with a corresponding pervasive societal belief that moral and ethical standards are declining and that ethical breaches are more readily tolerated
(Daniel, Elliott-Howard \& DuFrene, 1997). Fisher (2003) argues that while the concept of ethics is debated academically and while businesses establish codes of conduct, unethical practices in business and amongst business leaders continue to grow. Once unethical behaviour takes root in an organisation, it becomes a way of life in the organisational culture that makes it difficult for subsequent players to challenge (Demski, 2003). Commenting on the extent of corruption in business, a 2006 British study notes that business leaders are reported to be one of the groups least trusted by the general public (Institute of Business Ethics, 2007).

To promote sound governance in business, it is essential that organisations attract and retain ethical employees who are critical to the development and maintenance of ethical organisational cultures that promote competitive advantage (Almaric \& Hauser, 2005). Universities are the most readily available source from which such employees are recruited (ProcarioFoley \& Bean, 2002). Accordingly, when reflecting on the current levels of corruption, it is suggested that this reflects the diminished influence of universities in society both through their voice and through the graduates that they produce.

\section{Student academic dishonesty}

When focusing on students within our institutions, alarming trends are noted with regard to student academic honesty, with some hundreds of published articles and other scholarly works being devoted to such research (Whitley, 1998). Cheating during tests, plagiarising, buying assignment papers, falsifying data, using fraudulent excuses, getting others to write term papers and examinations, misusing resources and manipulating academic staff, can all be regarded as acts of academic dishonesty (Park, 2003; Pino \& Smith, 2003). These are the students who go on to become leaders in society, carrying with them the values that they later transmit into their own businesses. De Bruin and Rudnick (2007:153) note academic dishonesty among students to be 'a pervasive and ... growing problem in higher education settings', a sentiment echoed by others (Bolin, 2004; Dawkins, 2004; McCabe \& Trevino, 1993; Park, 2003; Whitley, 1998; Williams \& Hosek, 2003) with Levy and Rakovski (2006:736) stating that cheating in higher education 'is rampant'.

More specifically, some studies indicate that in excess of $75 \%$ of US college students have cheated at least once during their undergraduate degrees and that $80 \%$ of students about to attend US colleges have cheated sometime beforehand with over half of these students not considering cheating to be a serious transgression (Caron, Krauss-Whitbourne \& Halgin, 1992; Chapman, Davis, Toy \& Wright, 2004; Keohane, 1999; Kidwell, Wozniak \& Laurel, 2003; Roig \& Caso, 2005). At one 
South African university, De Bruin and Rudnick (2007) report that $38 \%$ of second year psychology students had cheated at least once during their academic careers.

As a component of academic dishonesty, an increase in plagiarism, specifically, has been witnessed (Born, 2003; Embleton \& Helfer, 2007; Sterngold, 2004), this being 'the act of using another's work without appropriate acknowledgment' (Devlin \& Gray, 2008: 182). In South Africa, Russouw (2005) reports that in 2004 more than 50 cases of plagiarism were reported at a single university and further mentions another university where 120 out of 150 undergraduate students interviewed admitted to regularly copying assignments from the Internet.

Findings from two Southern African countries note a strong correlation between student misconduct in examinations and their later ethics in business, with examination misconduct being predictive of a lack of business ethics (Gbadamosi, 2004). A link between other unethical behaviour at universities and later unethical behaviour in business has also been found (Bernardi, Giuliano, Komatsu, Potter \& Yamamoto, 2004; Granitz \& Loewy, 2007; Swift \& Nonis, 1998), and Desplaces, Melchar, Beauvais and Bosco (2007:73-74) note that 'after all, most of the executives and their subordinates caught in legal and ethical dilemmas hold business degrees, some from prestigious business schools'.

The enormity of student academic dishonesty becomes evident when imagining the kind of future leader that a plagiarist will make. Unethical students become unethical leaders. Universities may be complicit in facilitating such behaviour.

\section{Acts of omission}

While, necessarily, students themselves must take the blame for acts of academic dishonesty, additional complicity in such acts can be attributed to academics themselves. In a study that included over 1000 academics at 21 US campuses, over $30 \%$ of faculty did nothing to pursue cheating although they reportedly knew that it was occurring in their classes (Granitz \& Loewy, 2007). Another study notes that fewer than $25 \%$ of professors who suspected students to have presented fraudulent excuses required these students to provide proof for such excuses (Caron et al., 1992). Other researchers (Brimbel \& Stevenson-Clarke, 2006; Kidwell, 2001; Rawwas \& Isakson, 2000; Schneider, 1999) have commented upon the silence of professors towards academic cheating behaviour. In this vein, Lahm (2007) suggests that there is often a lack of academic enforcement of integrity policies and codes and that finding, documenting, prosecuting and dealing with the aftermath of student dishonesty is often regarded by academics as too time consuming. Lahm (2007) further reports that academics also find that there are consequences to their careers caused by addressing student dishonesty in terms of lower student ratings. He notes that institutions, themselves, do not deal with student academic dishonesty for fear of the risk to reputation that might arise from such exposure and the concomitant financial impact through declining enrolments and withdrawal of private sector funders. A literature search could not locate South African specific research that has investigated subtle academic complicity in student dishonesty, save a study currently in the field work stage to investigate this phenomenon (Thomas $\&$ de Bruin, in progress). Accordingly, the literature cited on this issue should be treated with caution in its application to the South African context.

\section{Overt participation in dishonesty by faculty}

Compounding student dishonesty and the avoidance by academics of dealing with it, the issue of dishonesty of academics and academic institutions themselves warrants attention.

Reports of academics being stripped of their degrees due to plagiarism and other acts of academic dishonesty are not uncommon in South Africa (Garson, 1993; Hoffman, 1998) and internationally (Bruhn, Zajac, Al-Kazemi \& Prescott, 2002; Gerdy, 2002), for example, in China (Jaccarino, Goldiner \& Gendar, 2008; Kelley \& Chang, 2007; Robertson, 2006; Wu, 2006), in the United States (Bartlett, 2003; Kersten, 2000; Meacham, 1993; Mulhauser, 2002; van der Werf, 2002), and in the United Kingdom (Walker, 2002). However, such reports appear to under-represent the picture with Bartlett and Smallwood (2004:A8) noting that it might seem that the only academic plagiarists are famous scholars with sloppy research assistants'.

Reasons stated for the lapse in ethics of academics include increased pressures to publish for career progression leading to opportunism, falsifying data and self-plagiarism (Embleton \& Helfer, 2007; Goodstein, 2002; Gundersen, Capozzoli \& Rajamma, 2008; Vinten, 2000), placing personal needs above honesty (Agle \& Kelley, 2001) and a lack of consensus within the academy on unacceptable faculty conduct (Bruhn et al., 2002). Reasons for a lack of action on the part of institutions, as a whole, to sanction academics who act unethically include fear of loss of industry support and grants, negative publicity and loss of reputation, avoidance of time-consuming disciplinary processes and collegial loyalty (Rhodes \& Strain, 2000). However, faculty dishonesty directly affects role modelling of ethical behaviour, personally and institutionally, to students and has been found to be significantly linked to student cheating behaviour (Schnake, Dumler \& Fredenberger, 2005). Stevens, Harris and Williamson (1994:146) state that 'a good case could be made for the premise that [business] students cannot be expected to be more ethical than the faculty who teach them'. 
Student academic dishonesty should be of paramount concern to educators especially considering the words of Piper, Gentile and Parks (1993:36) that 'students do not dwell in a vacuum. They mirror quite faithfully the central features of their culture and time'. The culture and time, in this instance, can also be thought of as including the university environment and context within which students study. Kidwell et al. (2003:213) note that 'what they learn as students in the classroom, is important, and should rightly be stressed, but just as important is how they learned it'.

While universities have attempted to address academic dishonesty through computer programmes (for example, software to detect plagiarism) (Devlin \& Gray, 2007) and processes (for example, ethics courses in the academic curriculum) (McWilliams \& Nahavandi, 2006; Pulley, 2005), it is primarily educators who have the responsibility for shaping the ethical vision that provides the foundation for the decisions students will later make in their own professions and work contexts (Pillsbury, 2004). In this vein, Piper et al. (1993:32) suggest that faculty are able 'to shape the ethical views of their students and to provide a beacon that offers a compelling direction in a business world that has lost its moral bearings'. Accordingly, Trevino (1986) notes that ethical behaviour is a complex system of interactions involving both personal and situational factors wherein student moral development and ethical behaviour can be considered components of a chain that includes the context within which such behaviour occurs i.e. the university (Williams \& Dewett, 2005).

While it appears to be obvious that faculty should address student academic dishonesty and that they, themselves, should serve as role models for ethical behaviour, what is less obvious is the role of the institution, as a whole, in setting an ethical climate as the context within which future leaders study. Studies have indicated that the ethical climate of a university directly determines student cheating (McCabe \& Trevino, 1993) and the retention of graduate students (Schulte, 2001).

\section{University culture, ethics and governance}

Habib and Morrow (2007) cite a 2002 Council on Higher Education report in which six of 12 South African university councils surveyed, were noted to be experiencing serious crises leading to deadlock or collapse. They state that some university councils in South Africa have 'hung back from decisive action on gross mismanagement', tending rather to focus on micromanagement of their institutions (Habib \& Morrow, 2007:127). Dibetle (2008), details the investigation by the Minister of Education into the poor running of a South African university where a prior 1999 investigation recommending dismissal of the vice-chancellor, was not acted upon by the university's council. A report some nine years later (Gower \& Dibetle, 2008) notes that this vice-chancellor, who has only recently been suspended, earns the highest salary of all the vice-chancellors of the 23 South African public universities.

Areas of gross transgressions on the part of academic staff, such as the manipulation of research data and overt race and gender discrimination, should be relatively easily addressed. However, the more subtle ethical transgressions that directly impact governance are often disguised and hidden within university structures and systems. Samier (2008) has termed such a presence 'passive evil' or in the words of Kets de Vries (1995:207) where, in the institutional culture 'a sense of reality gradually disappears and ... practices that would be considered questionable or even irrational ... go unchallenged'.

In order to understand this phenomenon, university culture, which is based upon 'values in practice' needs to be explored. The manner in which governance is defined within universities also furnishes insight into the foundations of governance that exist within these institutions.

Mora (2001:95) defines university culture as 'the beliefs of the members of the university community developed over centuries and transmitted both through language and symbols'. The culture of a university fundamentally determines the behaviour of members of the university community as well as its governance and decisionmaking. Adding to this, Keohane (1999:4) notes that the promotion of a strong academic community depends on the commitment of all members to five fundamental values: honesty, trust, fairness, respect and responsibility, and that 'from these values flow principles of behavior that enable academic communities to translate ideals into action'. Such action, of course, should impact society in the form of thought leadership and moral development.

University culture, as reflected in the overt artefacts of attitudes and behaviour, is a mirror of the adherence to or the 'living of' espoused values. In turn, values 'reflect underlying human motivations and shape the subsequent attitudes, speech, and actions' of people (Begley \& Stefkovich, 2007:399). Such values emerge from and continuously shape the ethical foundation of the institution. Irvin (2002:362) defines ethics as 'a system of accepted beliefs and principles of conduct typically based on moral imperatives that govern the behavior of individuals and the groups and organisations to which they belong'. Foucault (1977) stresses that ethics perform a governance function and that when actions that emerge from internalised values are reinforced, rewarded and normalised in an organisation, they form a standard of governance that then influences the actions of people and reinforces standards of behaviour.

Lazzeretti and Tavoletti (2006:21) note the difficulty of defining corporate governance in general, and argue that this is all the more so when the concept 'is extended to more hybrid and complex institutions 
like universities'. Middlehurst (1999) advances three general understandings of university governance. Firstly, governance is sometimes framed as the constitutional and legal framework that regulates the relationship between universities and governments. Secondly, governance is often regarded as the overall structure and process of internal co-ordination and control of the university. Finally, governance is seen as being the specific role and activities of the most senior committee of the university. These understandings of governance are reflected in common definitions of academic governance in the literature. Lazzeretti and Tavoletti (2006:21) describe university governance as referring to 'all processes and institutions that rule the division and managing of power inside universities and national university systems [where] ... power means making decisions that are binding for others'. The Council for Higher Education (CHE) (2002:5-6) notes that governance in universities involves '... ensur[ing] the efficiency of institutions to deliver with regard to teaching and research output to benefit society at large' while Kulati (2000:117) states that 'the new governance framework [for South Africa is] contained in the new higher education legislation'.

It is suggested that the above definitions highlight the problem with the apparently accepted blinkered concept of governance in universities that almost exclusively focuses on the creation and maintenance of legal and structural processes, designed for the efficient delivery of knowledge to society. Governance, it is proposed, is seen primarily as legalistic compliance with the Higher Education Act (Republic of South Africa, 1997) and other relevant legislation to which all South African organisations are bound. Together with this compliance, universities institute the structural agencies of governance such as councils, senates, institutional forums, faculty boards and other such entities. While it can be argued that compliance to the letter of the law is a necessary condition for the efficient functioning of universities and the governance within them, it is proposed that it is not a sufficient condition for all-embracing governance that demands that the 'spirit of the law' be equally addressed. In this regard, the respected definition of corporate governance by Cadbury (1992:1) should be borne in mind where corporate governance is 'concerned with holding the balance between economic and social goals and between individual and communal goals ... the aim is to align as nearly as possible the interests of individuals, corporations and society'. University governance requires a balance between the adherence to 'conformance' which involves accountability and compliance with legislation and other internal regulations (Garrat, 1990) and adherence to 'performance' where the development of direction and holistic strategy ensures the growth and sustainability of the institution (Garrat, 1990). However, it appears that universities have taken shelter in the legalities of governance (conformance) at the expense of embracing the spirit of governance in a multifaceted way (performance) that can ensure the development and maintenance of an ethical culture as a context for the education of future leaders. Similarly, a statement of institutional values and principles are necessary but also do not go far enough in developing an organisational culture where the internalisation of values and where the spirit of governance moderates overt and, in particular, covert behaviour in the institution.

The restricted definitions of governance that appear to be adopted by universities are translated into acts of omission, such as failure to address academic dishonesty, and active and passive participation relating to overt behaviours and covert practices respectively. Accordingly, a more comprehensive description of governance proposed for universities would include adherence to legislative and regulatory frameworks (conformance) coupled to which is the creation and ongoing development of an environment that nurtures the moral development of students and that of the staff who influence this process (performance).

\section{Changing priorities}

Universities have always been regarded as 'communities of scholars researching and teaching together in collegial ways' where those leading universities are viewed as 'academic leaders rather than managers and chief executives' (Deem, 1998:47). However, the demands that a changing, complex external world introduces, one of which universities are an integral part, have necessarily impacted universities. Such changes include an increasingly complex legal and educational environment, changing knowledge requirements, technological developments, rising costs and uncertain revenues, changes in staff and student demographics and demands, questions of quality and outputs, and external competition from 'for profit' education providers and consultants (Middlehurst, 1999). In addition to environmental challenges, faculty participation in governance is declining with few academics caring about or being involved in debating the nuances of ethical issues for academia, with other interests often taking greater precedence (Kezar \& Eckel, 2004).

Added to these challenges, are the ones specific to South African universities borne out of an historic legacy: mergers of institutions differing in degrees of historical privilege, with repercussions still being felt (Hall, Symes \& Luescher, 2004); the promotion of access to education for previously disadvantaged citizens and tensions between advancing equity and ensuring academic excellence where, according to Habib and Morrow (2007:120) 'there is in fact [still] a real tension between these two imperatives'. Habib and Morrow (2007) also allude to the less than market related salaries of established teachers and researchers, which, it can be argued, impacts the attraction and retention of such staff, especially those from previously disadvantaged groups. 
Rantz (2002:457) perhaps best summarises the impact of these demands by alluding to universities being 'under siege' from these internal and external challenges, requiring universities to respond to these environmental issues and compete more efficiently within shorter time frames (Kezar \& Eckel, 2004). This has resulted in universities becoming market oriented (Mora, 2001) and, increasingly, looking to business to provide resources (Reed \& Wellen, 2004). In this process a number of governance dilemmas arise, as will be discussed later in this paper.

Lazzeretti and Tavoletti (2006) describe the governance shifts in higher education over the decades. They note how governance started with the 'collegial model' evident at the earliest universities, through the 'bureaucratic-oligarchic model' and the 'democratic model' of universities as political organisations, to the 'new managerialism model' (Lazzeretti \& Tavoletti, 2006:25). In the latter model, universities approximate corporate institutions with ideals and concepts that are typical of businesses, where a culture of results as opposed to a culture of values is often the norm and where institutional values and integrity are lost (Sporn, 2001). This shift includes the generation of commercial activities by universities, the uncritical use of business practices and business consultants, and the 'manufacturing of graduates who can demonstrate an immediate return on society's investment in their education' (Koslowski, 2001:597). As a result, universities have become beholden to private donors and new venture business partners who also exercise a degree of external governance on such institutions (Delanty, 2002; Lazzeretti \& Tavoletti, 2006). Such external governance influence can lead to ambiguity and the abdication, by university leadership, of responsibility for the comprehensive governance of universities for themselves (Samier, 2008) as capitulation to external demands increases.

At this point it must be noted that the purpose of this paper is not to enter into the well-documented debate of the control of universities through government policy and structures. That is a task for further deliberation as it can be argued that such policies have contributed to the myopic definition of governance within universities as well as the abdication of internal responsibility for the monitoring of governance. Rather, an attempt is made in this paper to explore a more nuanced view of internal governance within universities, appreciating that universities should necessarily be committed to advancing transformation in a society that has emerged from historic systemic discrimination, as advocated by government policy.

The impact of the so-called managerial or entrepreneurial culture can be seen in a number of areas, most notably, in the reduction of knowledge to a commodity, in externally-dictated research agendas, in the loss of the 'lonely and extravagant thinker' who may now be at odds with external stakeholders (Weinberg \& Kistner, 2007:4), in career administrators and in internal and external competition between employees for financial rewards and 'corporate' status (Weinberg \& Kistner, 2007). With regard to the latter, Weinberg and Kistner (2007:4) believe that the position of a senior manager in a university has tended to displace 'traditional cultural capital - i.e. the professor as academic leader - in defining social position ... [giving] rise to unbridled careerism in the corridors of learning'.

Within this model, in a quest to compensate for low salaries, universities tend to permit their academics to supplement their income through consulting and contract research opportunities. In addition, in an endeavour to address financial pressures, universities, themselves, have also introduced revenue-generating executive education or extra-curricular activities. On the surface this is an ideal arrangement as it helps supplement academic salaries for those who teach on these programmes, as well as meet the financial needs of the university. It can also be argued that such programmes are responding to a broad identified need for education in society. However, governance issues arise in the execution of these endeavours and herein lies some of the governance challenges that universities have failed to address.

Few guidelines exist to govern the practices related to market-oriented programmes or the transparency of such operations in the interests of all stakeholders. In many cases this results in favouritism in teaching allocations and the de-prioritisation of mainstream academic work, such as research and teaching. It also promotes a two-tier academic system where favoured staff who choose not to involve themselves in contributing to the development of the university are remunerated more handsomely than those who take their formal teaching and research responsibilities seriously. Further, often no appropriate action is taken against academics and administrators who use the system for their own gain, and transgressions are overlooked or forgiven as the university derives significant revenue from such operations.

\section{Organisational culture}

In addition to the above practices, passive practices that challenge sound governance are evident within universities in the area of embedded organisational culture. Perhaps what has insidiously happened in universities is the omission, by academic leaders, to take time out of busy 'corporate schedules' to collegially debate the values of the institution in order to arrive at a shared understanding of their meaning. Such shared understanding of meaning then becomes the heart of the organisational culture that drives institutional behaviour and governance. 
Instead, behaviour that appears alien to a true collegial environment often prevails such as harassment and aggression that ultimately leads to the breakdown of collegiality (Blase \& Blase, 2004), practices of humiliation and marginalisation of high achieving academics (Westhues, 2005) and leaving young academics to 'sink or swim' (Cabral-Cardosa, 2004). Cooper (1987) proposes that challenging authority in universities can often lead to retribution, career damage, marginalisation or even expulsion, regardless of the quality of one's work while Cabral-Cardosa (2004) notes that support systems are not in place for junior faculty to challenge senior faculty when members close ranks against such whistle blowers.

In South Africa, suppressed subtle racism has surfaced at many institutions as open conflict, such as that symbolised in periodic student unrest. It is not uncommon that academics who may be 'different' to the norm in terms of race, culture or language are subtly excluded from the 'inner circle' leading them to seek alternative employment. Nor is it uncommon that hostile cultures are perpetrated by 'untouchable' tenured professors and senior academics where 'collegiality' is no longer a term that characterises relationships within departments.

Blase and Blase (2004:254) term the above 'the dark side' of academia. Samier (2008:3) extends this observation by referring to academic colleagues who, through inaction, support such acts as engaging in 'passive evil'. In these cases, accountability 'is defined in relation to political and bureaucratic authorities and formalised goals instead of higher order moral principle' and formal organisational authority is substituted for ethics and moral imperatives (Samier, 2008:3). Bird and Waters (1989) coined the term 'moral muteness' for such behaviour.

Sound governance requires that the 'the dark side' of academia (Samier, 2008:3) is addressed where, through intellectual or moral accountability by means of peer review, such practices are highlighted and action is taken. However, this appears not to happen as the responsibility for governance has shifted from an internal imperative to external compliance with government audits and other funding pressures where a greater number of external actors are drawn into the arenas of power to exert 'governance' through management principles and legal accountability.

In summary, it is reiterated that the existence of universities is based on the mandate of developing thought and moral leadership in society. As such, it is not enough to merely teach ethics and governance within the academic curriculum. Universities should be role models themselves. Delanty (2002) notes that while the question of how universities should be governed, needs to be asked, a more critical question to ask is how universities ensure that they, themselves, take responsibility for their own governance.

\section{Challenges to universities - the development of institutional moral responsibility}

While compliance with legislation and procedures is necessary, such compliance does not go far enough to ensure that universities are well governed and provide an ethical environment that nurtures student learning and development. What is needed is the broader development of a foundation of institutional 'moral responsibility' (Iltis, 2001) within which institutional governance is housed. Such moral responsibility is grounded in institutional integrity or what an institution's moral commitments ought to be, what it ought to value and that to which it ought to be committed. These moral commitments are an institution's moral character and determine how the tension between governance dilemmas are addressed. The development of moral character demands internal introspection. Accordingly, drawing on the competence framework proposed by Rossouw (2004), some key challenges to universities to support the development of overall institutional moral responsibility are addressed, using the analogy of the head, the heart and the hands. The issues raised give rise to three overarching questions that are posed, as a start, to guide introspection about the development of institutional moral responsibility.

\section{Developing institutional moral competence in the cognitive realm (the head)}

While it is accepted that universities must facilitate the development of critical thought in students and contribute to their moral development (Conroy \& Emerson, 2004), some attention should be focused on how the university, itself, develops critical thought. This would start with introspection, an understanding of the current state, a surfacing of and a focus on the culture of the university and on some of the 'unspoken rules' that drive attitudes and behaviours, in an 'effort to establish a culture of academic integrity' (Kidwell et al., 2003:205). In this regard, current practices need to be debated against a background of the values of honesty, trust, fairness, respect and responsibility (Keohane,1999), as a means of developing an organisational culture that promotes collegiality and a common understanding of university culture and the academic 'ethic'.

This exercise demands going beyond the satisfaction of knowing that university principles and values have been established and disseminated. It involves understanding the 'extent [that such] principles are incorporated into daily actions ... [and] the development of a culture incorporating ethical values that is conducive to ethical behaviour' (Cabral-Cardosa, 2004:83). It further involves identifying assumptions, making them explicit and then examining them critically (Morrell \& Anderson, 2006). Castro (2001:416) notes that the degree to which we have specialised away from such a sense of shared purpose is a sensitive issue because it questions 
the appropriateness of our training, of our means of organising ourselves and our curricula, and perhaps our professional identities'.

This process, which operates at a cognitive level, develops through the understanding of the moral obligations for fulfilling the university mandate, appreciating the moral dilemmas that arise from both this task and the internal and external challenges that impact universities, evaluating different ethical options and drawing on tools to assist in making decisions relating to these choices (Rossouw, 2004). Essentially developing moral competence in the cognitive realm involves developing an institutional mind capable of conceptualising the reasons for sound governance that encapsulate the spirit of governance over mere adherence to the law of governance.

\section{Developing institutional moral competence in the behavioural realm (the heart)}

According to Rossouw (2004), developing institutional moral competence in the behavioural realm involves assessing the impact of decisions on all stakeholders, checking the power of stakeholders and interrogating established norms (Morrell \& Anderson, 2006), developing the moral courage to act on moral convictions and creatively imagining solutions from a variety of perspectives. This involves a review of university adherence to a 'managerial philosophy' and the implications of such for the abdication of responsibility for internal governance in favour of allowing purely external controls, such as legislation or funders, to be the sole determinants of institutional practices. It involves understanding how the needs of all stakeholders (external and internal) must be balanced and arriving at a position where the integrity of the academic ethic is respected while strategies to address the requirements of a changing environment are appreciated. Institutional passion for living the principles of sound governance must be developed and staff must be inspired to do the same. Conceivably, ways must be contemplated of rewarding staff who, by their behaviour, institutionalise moral responsibility and attendant governance practices.

\section{Developing institutional moral competence in the managerial realm (the hands)}

Essentially, the development of managerial moral competence involves 'the ability to translate ethical concerns and considerations into organisational practice' (Rossouw, 2004:40). In this regard, universities need to act in ways that institutionalise sound governance, which, in turn, is modelled to students by all academic leaders and faculty. Accountability of staff for their actions must be assessed against the description of university governance furnished earlier, where adherence to the letter of the law and regulations is not enough and where a requirement exists for staff to actively cultivate, through their behaviours towards colleagues and students, an institutional culture that nurtures moral development. Developing moral competence in the managerial realm requires staff to demonstrate moral integrity in their role modelling to students in addition to their observance of moral integrity in their teaching and research activities. In summarising this position, O'Connell (1998:168) notes that 'our task in universities is not only to teach ethics and values for the marketplace but to model these values ourselves as we fulfil our own moral responsibility as educators in the universities where our students begin the [business] ethics journey in the first place'. Accordingly, universities need to act with integrity in aligning and implementing the development of moral competence in all three realms, which necessarily will involve addressing governance dilemmas that revolve around efficiency, effectiveness, participation and responsiveness (Kezar \& Eckel, 2004). Such dilemmas which illustrate the performance/ conformance tension include:

- pushing entrepreneurial boundaries as demanded by, for example, new technologies or the need to secure income (performance) while still remaining true to academic principles and values that are internally developed (conformance);

- ensuring accountability of staff (conformance) yet providing the environment for creativity and innovation unfettered by bureaucracy (performance);

- achieving quality decisions based on competence that may reside outside the institution (conformance) while still promoting collegial inclusiveness in academic decision-making (performance);

- involving internal and external stakeholders in processes that yield strategic direction (conformance), yet maintaining academic integrity in its implementation, underscored by the values of the institution (performance); and

- addressing access to education required by South African national imperatives (conformance) while staying true to promoting academic quality (performance).

It is important for universities to respond to and, in fact, be proactive to external challenges without losing internal integrity. Some of these dilemmas, as noted above, are not about choosing one practice above the other; rather there is a need to hold the tension and manage both components of the dilemma with integrity. It is suggested that such management requires creativity together with a grounding in the guiding values and ethics of the institution.

What is advocated is leadership that promotes the development of an organisational culture where internal ethical behaviour, both of the institution as a whole and of its members leads to comprehensive governance; 
where governance dilemmas are creatively managed and where we 'understand that our own organisational practices should serve as an example of the values and attitudes we convey to our students' (UN Global Compact, 2007:4).

In summary, the three questions that can serve as a starting point to guide institutional introspection are:

- In academia, what thoughts, emotions and actions provide evidence of the development of moral responsibility that lays the basis for sound institutional governance?

- How can the integrity of the process of aligning the head, the heart and the hands in order to develop institutional moral responsibility be evaluated?

- Who should evaluate the evidence?

\section{Conclusion}

Braun and Merrien (1999:2) note that ideally, the organisation of a university is based on communities of academics 'united in the same ideal' and one that 'advances the quest for truth and knowledge by requiring intellectual and personal honesty in teaching, research and service' (Keohane, 1999:5). Such communities of academics promote the fulfilling of the university mandates of developing thought and moral leadership in society. However, the development of moral leadership through graduands is not solely related to the teaching of ethics courses; it demands a renewed responsibility for internal self-governance by academics themselves and a commitment to the development of institutional moral responsibility. Such moral responsibility lays the foundation for institutional governance that supplements compliance with external laws and other regulators. Developing moral responsibility requires the crafting of institutional culture by leadership where the translation of institutional values into governance practices is evident in the attitudes and behaviours of academic and administrative staff alike. Such a culture creates an environment of integrity that provides a context for the development of students who, as future leaders, have the potential to impact society for the good.

\section{References}

Agle, B.B. \& Kelley, P.C. 2001. Ensuring validity in the measurement of corporate social performance: Lessons from corporate United Way and PAC campaigns. Journal of Business Ethics, 31: 271-284.

Almaric, F. \& Hauser, J. 2005. Economic drivers of corporate responsibility activities. The Journal of Corporate Citizenship, Winter (20): 27-38.

Bartlett, T. 2003. A textbook example. The Chronicle of Higher Education: 49, 42.

Bartlett, T. \& Smallwood, S. 2004. Four academic plagiarists you've never heard of: How many more are out there? The Chronicle of Higher Education, 51(17): A8-A12.
Begley, P.T. \& Stefkovich, J. 2007. Integrating values and ethics into post secondary teaching for leadership development: Principles, concepts and strategies. Journal of Educational Administration, 45(4): 398-412.

Bernardi, R.A., Giuliano, J.L., Komatsu, E., Potter, B.M. \& Yamamoto, S. 2004. Contrasting the cheating behaviours of college students from the United States and Japan. Global Virtue Ethics Review, 5(4): 5-31.

Bird, F.B. \& Waters, J.A. 1989. The moral muteness of managers. California Management Review, 32(1): 73-88.

Blase, J. \& Blase, J. 2004. The dark side of school leadership: Implications for administrator preparation. Leadership and Policy in Schools, 3(4): 245-273.

Bok, D. 1990. Universities and the future of America. Durham NC: Duke University Press.

Bolin, A.U. 2004. Self-control, perceived opportunity, and attitudes as predictors of academic dishonesty. Journal of Psychology: Interdisciplinary and Applied, 138: 101-114.

Born, A.D. 2003. How to reduce plagiarism. Journal of Information Systems Education, 14(3): 223-224.

Braun, D. \& Merrien, F. 1999. Toward a new model of governance for universities: A comparative view. London: Jessica Kingsley.

Bruhn, J.G., Zajac, G., Al-Kazemi, A.A. \& Prescott, L.D. Jr. 2002. Moral positions and academic conduct: Parameters of tolerance for ethics failure. Journal of Higher Education, 73(4): 461-493.

Cabral-Cardosa, C. 2004. Ethical misconduct in the business school: A case of plagiarism that turned bitter. Journal of Business Ethics, 49: 75-89.

Cadbury Report. 1992. The financial aspects of corporate governance. London: Gee.

Caron, M.D., Krauss-Whitbourne, S.K. \& Halgin, R.P. 1992. Fraudulent excuse making among college students. Teaching of Psychology, 19: 90-93.

Castro, B. 2001, Business ethics: Brightening the corner where we are. Teaching Business Ethics, 5: 411-418.

Chapman, K.J., Davis, R., Toy, D. \& Wright, L. 2004. Academic integrity in the business school environment: I'll get by with a little help from my friends. Journal of Marketing Education, 26: 236-249.

Committee of University Chairmen. 1998. Guide for members of governing bodies of universities and colleges in England, Wales and Northern Ireland. March 98/12. Bristol: HEFCE.

Conroy, S. \& Emerson, T. 2004. Business education and religion: Religiosity as a predictor of ethical awareness among students. Journal of Business Ethics, 50: 383-396.

Control Risks Group. 2006. Global corruption survey. [Online]. Available: www.controlrisks.com/PDF/ corruptionsurvey2006. Accessed on 29 September 2008.

Cooper, T. 1987. Hierarchy, virtue, and the practice of public administration: A perspective for normative ethics. Public Administration Review, 47: 320-328.

Council on Higher Education (CHE). 2002. Promoting good governance in South African higher education. Pretoria: Council on Higher Education.

Council on Higher Education (CHE). 2008. Academic freedom, institutional autonomy and public accountability in South African higher education. Report of the Independent Task Team on Higher Education, Institutional Autonomy and Academic Freedom. Pretoria: Council on Higher Education. 
Daniel, L.G., Elliott-Howard, F. \& DuFrene, D.D. 1997. The ethical issues rating scale: An instrument for measuring ethical orientation of college students toward various business practices. Educational and Psychological Measurement, 57: 515-526.

Dawkins, R.L. 2004. Attributes and statuses of college students associated with classroom cheating on a smallsized campus. College Student Journal, 38: 116-129.

De Bruin, G.P. \& Rudnick, H. 2007. Examining the cheats: The role of conscientiousness and excitement seeking in academic dishonesty. South African Journal of Industrial Psychology, 37(1): 153-164.

Deem, R. 1998. 'New managerialism' and higher education: The management of performances and cultures in universities in the United Kingdom. International Studies in Sociology of Education, 8(1): 47-70.

Delanty, G. 2002. The governance of universities: What is the role of the university in the knowledge society? Canadian Journal of Sociology, 27(2): 185-198.

Demski, J.S. 2003. Corporate conflicts of interest. Journal of Economic Perspectives, 17(2): 51-72.

Desplaces, D.E., Melchar, D.E., Beauvais, L.L. \& Bosco, S.M. 2007. The impact of business education on moral judgment competence: An empirical study. Journal of Business Ethics, 74: 73-87.

Devlin, M. \& Gray, K. 2007: In their own words: A qualitative study of the reasons Australian university students plagarize. Higher Education Research and Development, 26(2): 1811-198.

Dibetle, M. 2008. Team to probe university. Mail and Guardian, September: 19-25, 14.

Eliot, T.S. 1962. Notes towards the definition of culture. [Originally published in 1943.] London: Faber and Faber.

Embleton, K. \& Helfer, D.S. 2007. The plague of plagiarism and academic dishonesty. Searcher, 15(6): 23-26.

Fisher, J. 2003. Surface and deep approaches to business ethics. Leadership and Organization Development Journal, 24(2): 96-101.

Foucault, M. 1977. Discipline and punish: The birth of the prison. London: Penguin.

Garrat, R. 1990. The fish rots from the head. London: HarperCollinsBusiness.

Garson, P. 1993. Nkondo's PhD: In his own words? Mail and Guardian, 9(37): 9.

Gbadamosi, G. 2004. Academic ethics: What has morality, culture and administration got to do with its measurement? Management Decision, 42(9): 1145-1161.

Gerdy, J. 2002. Athletic victories, educational defeats. Academe, 35: 1-7.

Goodstein, D. 2002. Scientific misconduct. Academe, 1: 28-31.

Gower, P. \& Dibetle, M. 2008. The vice in VC. Mail and Guardian, 24(44): 7

Granitz, N \& Loewy, D. 2007. Applying ethical theories: Interpreting and responding to student plagiarism. Journal of Business Ethics, 72: 293-306.

Gundersen, D.E., Capozzoli, E.A. \& Rajamma, R.K. 2008. Learned ethical behaviour: An academic perspective. Journal of Education for Business, July/August: 315-324.

Habib, A. \& Morrow, S. 2007. Research, research productivity and the state in South Africa. Journal of Higher Education Research, 5(1): 113-130.
Hall, M., Symes, A. \& Luescher, T. 2004. The governance of mergers in South African Higher Education. Research report prepared for the Council on Higher Education. Pretoria: Council on Higher Education.

Hawawini, G. 2005. The future of business schools. Journal of Management Development, 24(9): 770-782.

Hoffman, H. 1998. Heath se span kyk na die sake in Venda. Beeld. (28 July, 1998). p. 13.

Hogness, J.R. 1986. The essence of education: Ethics and morality. Vital Speeches of the Day, 52: 561-563.

Howard, J.A. 1986. Higher education and civilization in trouble: Producing a virtuous populace. Vital Speeches of the Day, 55: 314-318.

Iltis, A.S. 2001. Organizational ethics and institutional integrity. HEC Forum, 13(4): 317-328.

Institute of Business Ethics. 2007. Surveys on business ethics 2006. London: IBE.

Irvin, L. 2002. Ethics in organizations: A chaos perspective. Journal of Organizational Change Management, 15(4): 359-381.

Jaccarino, M., Goldiner, D. \& Gendar, A. 2008. Fired noose prof rips plagiarism rap. New York Daily News. (25 June, 2008). p. 12.

Kelley, P.C. \& Chang, P.L. 2007. A typology of university ethical lapses: Types, levels of seriousness, and originating location. The Journal of Higher Education, 78(4): 402-429.

Keohane, N.O. 1999. The fundamental values of academic integrity. Durham, North Carolina: Duke University, The Center for Academic Integrity.

Kets de Vries, M. 1995. Life and death in the executive fast lane: Essays on irrational organizations and their leaders. San Francisco: Jossey-Bass.

Kezar, A. \& Eckel, P.D. 2004. Meeting today's governance challenges: A synthesis of the literature and examination of a future agenda for scholarship. Journal of Higher Education, 75(4): 371-399.

Kidwell, L.A. 2001. Student honor codes as a tool for teaching professional ethics. Journal of Business Ethics, 29: 45-49.

Kidwell, L.A, Woziak, K \& Laurel, J.P. 2003 Student reports and faculty perceptions of academic dishonesty. Teaching Business Ethics, 7: 205-214.

Koslowski, D. 2001. Think carefully. Vital Speeches of the Day, 67(19): 594-596.

Kulati, T. 2000. Governance, leadership and institutional change in South African higher education: Grappling with instability. Tertiary Education and Management, 6(3): 117-192.

Lahm, R.J. 2007. Plagiarism and business plans: A growing challenge for entrepreneurship education? Journal of Entrepreneurship Education, 10: 73-84.

Lazzeretti, L. \& Tavoletti, E. 2006. Governance shifts in higher education: A cross-national comparison. European Educational Research Journal, 5(1): 18-37.

Leroy Long, E. 1992. Higher education as a moral enterprise. Washington, D.C.: Georgetown University Press.

Levy, E.S. \& Rakovski, C.C. 2006. Academic dishonesty: A zero tolerance - professor and student registration choices. Research in Higher Education, 47(6): 735-754.

Lickona, T. 1991. Educating for character: How our schools can teach respect and responsibility. New York, NY: Bantam Books. 
Martin, J.S. \& Marion, R. 2005. Higher education leadership roles in knowledge processing. The Learning Organisation, 12(2): 140-151.

McAlpine, L. \& Harris, R. 2002. Evaluating teaching effectiveness and teaching improvement: A language for institutional policies and academic development practices. The International Journal for Academic Development, 7(1): 7-17.

McBee, M.L. 1980. New directions in higher education: Rethinking college responsibility for values. San Francisco: Jossey-Bass.

McCabe, D.L. \& Trevino, L.K. 1993. Academic dishonesty: Honor codes and other contextual influences. Journal of Higher Education, 64: 520-528.

McWillaims, V. \& Nahavandi, A. 2006. Using live cases to teach ethics. Journal of Business Ethics, 67: 421-433.

Meacham, J. 1993. Class dismissed: Universities should start caring about how well - and how much - teachers teach. Washington Monthly, 42(5): 5.

Middlehurst, R. 1999. New realities for leadership and governance in higher education. Tertiary Education and Management, 5(4): 307-329.

Mora, J.G. 2001. Governance and management in the new university. Tertiary Education and Management, 7(2): 95-107.

Morrell, K. \& Anderson, M. 2006. Dialogue and scrutiny in organizational ethics. Business Ethics: A European Review, 15(2): 117-129.

Mulhauser, D. 2002. A matter of degree. The Chronicle of Higher Education, 48: 18.

O'Connell, D.W. 1998: From universities to the marketplace: The business ethics journey. Journal of Business Ethics, 17: 1617-1622.

Park, C. 2003. In other (people's) words: Plagiarism by university students - literature and lessons. Assessment and Evaluation in Higher Education, 28: 471-488.

Pillsbury, C. 2004. Reflections of academic misconduct: An investigating officer's experiences and ethics supplements. Journal of American Academy of Business, 5(1/2): 446-454.

Pino, N.W. \& Smith, W.L. 2003. College students and academic dishonesty. College Student Journal, 37: 490500.

Piper, T.R., Gentile, M.C. \& Parks, S.D. 1993. Can ethics be taught? Perspectives, challenges and approaches at Harvard Business School. Cambridge MA: Harvard Business Press.

Pounder, J.S. 2001. 'New leadership' and university organisational effectiveness: Exploring the relationship. Leadership and Organization Development Journal, 22(5-6): 281-290.

Pounder, J.S. 2002. Public accountability in Hong Kong higher education. The International Journal of Public Sector Management, 15(6/7): 458-474.

Procario-Foley, E.G. \& Bean, D.F. 2002. Institutions of higher education: Cornerstones in building ethical organizations. Teaching Business Ethics, 6(1): 101-116.

Pulley, J.L. 2005 More schools are teaching social and environmental ethics. The Chronicle of Higher Education, 52(10): A.34.

Rantz, R. 2002. Leading urban institutions of higher education in the new millennium. Leadership and Organization Development Journal, 23(8): 456-466.
Rawwas, M.Y.A. \& Isakson, H.R. 2000. Ethics of tomorrow's business managers. Journal of Education for Business, 75(6): 321-331.

Reed, D. \& Wellen, R. 2004. Introduction. Journal of Academic Ethics, 2: 1-2.

Republic of South Africa. 1997. Higher Education Act No. 101, as amended by the Higher Education Amendment Act No. 55 of 1999, Higher Education Amendment Act No. 54 of 2000, Higher Education Amendment Act No23 of 2001. Pretoria: The Government Printer.

Rhodes, R. \& Strain, J.J. 2000. Trust and transforming medical institutions. Cambridge Quarterly of Healthcare Ethics, 9: 205-217.

Robertson, B. 2006. VOA news: China's universities struggle with academic plagiarism. US Federal News Service, 10 June.

Roig, M. \& Caso, M. 2005. Lying and cheating: Fraudulent excuse making, cheating, and plagiarism. The Journal of Psychology, 139(6): 485-494.

Rossouw, D. 2004. Developing business ethics as an academic field. Johannesburg: BEN-Africa.

Russouw, S. 2005. Cheats netted in hi-tech trap. Saturday Weekend Argus. (25 February, 2005). p. 1.

Samier, E. 2008. The problem of passive evil in educational administration: Moral implications of doing nothing. International Studies in Educational Administration, 36(1): 2-21.

Schnake, M., Dumler, M.P. \& Fredenberger, W. 2005. Predicting overall ethical climate, student retention, cheating, satisfaction with university, and perceived stress with student perceptions of faculty unethical behaviour. Academy of Educational Leadership Journal, 9(3): 31-39.

Schneider, A. 1999: Why professors don't do more to stop students who cheat. The Chronicle of Higher Education, 22: A8.

Schulte, L.E. 2001. Graduate education faculty and student perceptions of ethical climate and its importance in the retention of students. College Student Retention, 3: 119-136.

Sporn, B. 2001. Building adaptive universities: Emerging organisational forms based on experiences of European and US universities. Tertiary Education and Management, 7(2): 121-134.

Sterngold, A. 2004. Confronting plagiarism. Change, 36: 16-21.

Stevens, R.E., Harris, O.J. \& Williamson, S. 1994. Evaluations of unethical situations by university faculty: A comparative study. Journal of Education for Business, 69: 145-150.

Swift, C.O. \& Nonis, S. 1998. When no one is watching: Cheating behaviors on projects and assignments. Marketing Education Review, 8: 27-36.

Thomas, A. \& de Bruin, D. (in progress). Upholding ethics in academia: Grading the teachers. Research currently in progress at the University of Johannesburg.

Trevino, L.K. 1986. Ethical decision making in organizations: A person-situation interactionist model. Academy of Management Review, 11(3): 601-617.

UN Global Compact. 2007. The principles for responsible management education. New York: United Nations.

Van der Werf, M. 2002. Professor punished for consulting. The Chronicle of Higher Education, 49: 16. 
Vinten, G 2000. The business school in the new millennium. The International Journal of Educational Management, 14(4): 180-191.

Walker, D. 2002. 2 Oxford professors quit after sting. The Chronicle of Higher Education, 48: 30.

Weinberg, G.S. \& Kistner, U. 2007. Introduction: From ivory tower to market place: What future for the university in South Africa? Journal of Higher Education in Africa, 5(1): $1-7$.

Westhues, K. 2005. The envy of excellence: Administrative mobbing of high-achieving professors. Lewiston: Edwin Mellon Press.

Whitley, B.E. Jr. 1998. Factors associated with cheating among college students: A review. Research in Higher Education, 39: 235-274.

Williams, M.S. \& Hosek, W.R. 2003. Strategies for reducing academic dishonesty. Journal of Legal Studies Education, 21: 87-92.
Williams, S.D. \& Dewett, T. 2005. Yes, you can teach business ethics: A review and research agenda. Journal of Leadership and Organizational Studies, 12(2): 109-120.

$\mathrm{Wu}$, V. 2006. Plagiarism case resounds beyond academic circles. South China Morning Post. (April 24, 2006). p. 6.

Address correspondence to: Prof Adèle Thomas

Department of Business Management University of Johannesburg

PO Box 524

Auckland Park, 2006

Johannesburg, South Africa

e-mail: adelet@uj.ac.za 
Reproduced with permission of the copyright owner. Further reproduction prohibited without permission. 